\title{
The Efficiency of rhBMP-7 in Oral and Maxillofacial Bone Defects: A Systematic Review
}

\author{
Nur Hatab ${ }^{1, *}$, Tulsie Patel2 ${ }^{2}$ Aya Bakkour ${ }^{3}$ \\ RAK College of Dental Sciences, RAK Medical and Health Sciences University, Ras Al Khaimah, United Arab Emirates (UAE) \\ 1 Senior Lecturer, DMD, PhD \\ 2 Student, BDS \\ ${ }^{3}$ Student, BDS
}

\section{ABOUT ARTICLE}

Article history:

Paper received 10 June 2017

Accepted 11 June 2017

Available online 30 June 2017

\section{Keywords:}

Recombinant human bone morphogenic protein-7 (rhBMP-7)

Recombinant therapy

Osteogenic protien-1 (OP-1)

Guided tissue regeneration (GTR)

\begin{abstract}
A B S T R A C T
Background.

Bone morphogenic protein-7 (BMP-7) is a molecule that has been clinically trialed and tested for use in regeneration of bone defects and its ability to induce bone formation by induction of gene expression [11]. Recombinant human BMP-7 (rhBMP-7) has surgical uses and is marketed under the brand name OP-1 (Olympus Biotech Corporation, ). With the ever expanding discipline of oral surgery and the need for regenerative therapy for bone defects in the oral and maxillofacial region, this study was undertaken to compare the outcomes of different methods of use of BMP-7. Methods.

The authors retrieved English publications on relevant studies from PubMed, ScienceDirect and Google Scholar from 2000 to 2016. In vitro and in vivo studies were included. The main outcomes were increased expression of osteogenic genes and radiographic bone fill.

Results.

In total, 676 human studies in the literature were identified but only four were ultimately feasible. The results showed a significant effect of rhBMP-7 both in-vitro and in-vivo. In all the studies used a systematic review was used to compare the outcomes of using rhBMP-7. The in vivo samples showed significant radiographic fill and efficient bone deposition [4]. In vitro studies showed increased expression of OCN and ALP biomarkers.

Conclusions.

rhBMP-7 is an effective tool that can be used to improve and speed up regenerative therapy of bone defects. However further human studies are needed to enhance and develop the use of this molecule in vitro.

(C) Diagnostics and Treatment of Oral and Maxillofacial Pathology. Published by OMF Publishing, LLC. All rights reserved.
\end{abstract}

\section{Intoduction}

Periodontal disease as well as bacterial bone infections can result in different types of defects in the alveolar and maxillofacial bone [1]. There are two types of periodontal bone defects infrabony defects and craters. Infrabony defects happen when bone resorption occurs unevenly in an oblique direction. In infrabony defects, the bone loss is generally restricted to one tooth [2]. Other bone defects are as a result of infection such as osteomyelitis and the presence or removal of cysts and tumors. The importance of repair and healing to prevent further bone loss or tooth loss is of great importance. Bone morphogenetic protein-7 (BMP-7) is a protein that stimulates and encourages growth of bone around many skeletal sites including the craniofacial bones [2]. It's expressed in the

\footnotetext{
${ }^{*}$ Corresponding author. Oral and Maxillofacial Surgery, RAK College of Dental Sciences, RAK Medical \& Health Sciences University, UAE Tel.: +97154 4297376

E-mail address: nur.hatab@rakmhsu.ac.ae (Nur Hatab)
}

brain, kidneys and the bladder [3]. BMP-7 has been found to enhance growth around teeth, dental implants and the maxillary sinus floor [4]. Like other members of the bone morphogenetic protein family of proteins, it plays a key role in the transformation of mesenchymal cells into bone and cartilage. It has been demonstrated that BMP-7 treatment is sufficient to induce all of the genetic markers of osteoblast differentiation in many cell types [4]. RhBMP-7 is a protein molecule that has previously been used to repair osteogenic defects. This project will investigate publications that are analyzing the efficiency of rhBMP-7 on bony defects and their ability to cause bone regeneration. RhBMP-7 is a protein molecule that has previously been used to induce repair of osteogenic defects. This project will investigate publications that are dealing with efficiency of rhBMP-7 and analyzing the efficiency of rhBMP-7 on bone defects and their ability to induce bone regeneration in the oral and maxillofacial region. 


\section{Review of the Literature}

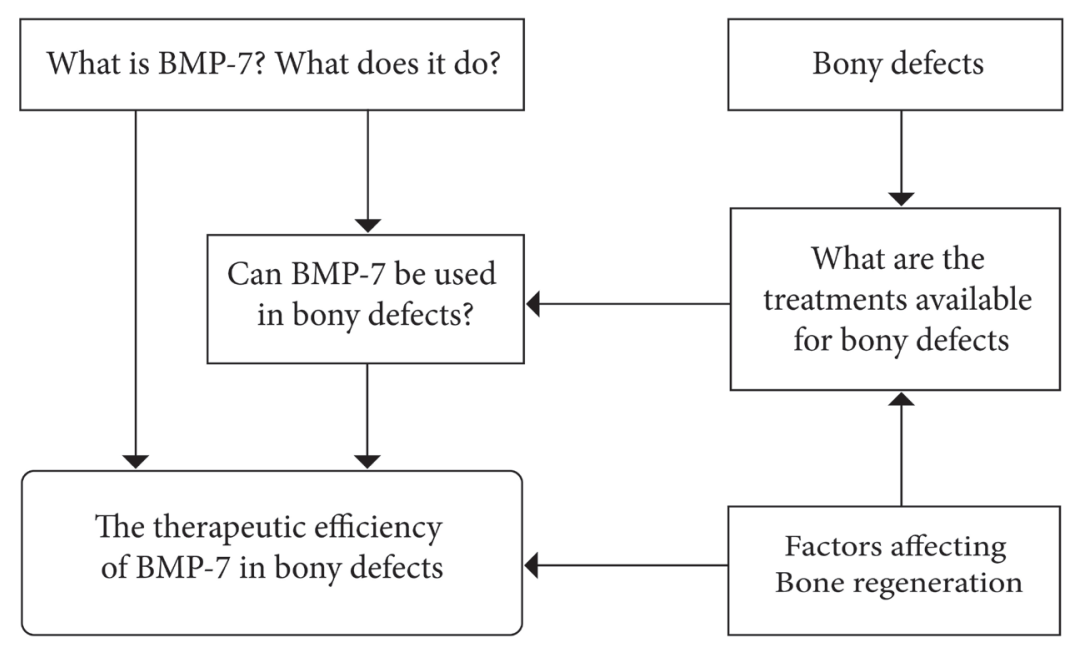

FIGURE 1. Theoretical framework

BMP-7 is a transforming growth factor that has the ability to regenerate bone at osteonomic defects and implants sites. The BMP-7 bone morphogenetic protein is also called the osteogenic protein-1 (OP-1). There have been few experiments done with BMP-7 as it is quite a recent development in comparison to other forms of gene therapy. Not only is BMP-7 therapeutic in bone defects (Fig 1) it is also being trialed for pulp mineralization. Other applications include renal therapy and as an anti-fibrotic therapy for diabetic nephropathy. Tissue engineering of alveolar bone surrounding implants involves targeted and sustained delivery of growth promoting molecules. They control the growth and formation of cartilage and bone during embryo development and after birth [5].

Bone morphogenetic proteins form a unique group of proteins within the transforming growth factor superfamily of genes and have a vital role in the regulation in the bone induction and maintenance [3]. Alveolar bone supports the tooth and implant structure, i.e. the jaw bones. This alveolar bone can be destroyed when teeth are lost due to trauma or disease. Therefore it is important that after tooth loss this bone regenerates and repairs itself. Currently there are treatments which are used to heal this alveolar bone. Periodontitis is an infectious inflammatory disease that results in attachment loss and alveolar bone loss. Periodontal tissue repair or regeneration involves production of new cementum, periodontal ligament, and alveolar bone. Several studies have been undertaken to investigate the best way to reproduce and mimic periodontal tissues [6]. Bone formation and regeneration is the most important aspect of successful periodontal therapy. The activity of bone morphogenetic proteins was first discovered in the 1960's, but the proteins responsible for bone induction were unknown until the 1980's. Because of their osteoinductive ability, bone morphogenetic proteins have gained a lot of interest as treatment options and adjuncts for periodontal defects [6].
BMP 7 has been proposed as a therapy for bone regeneration and Pulp mineralization in root part of pulp. General uses of bmp-7 also include kidney therapy. BMP7 is expressed in brain kidneys and bladder. The protein encoded by this gene is a member of the TGF- $\beta$ superfamily. Like other members of the bone morphogenetic protein family of proteins, it plays a key role in the transformation of mesenchymal cells into bone and cartilage. It is inhibited by noggin and a similar protein, chordin, which are expressed in the Spemann-Mangold Organizer. BMP7 may be involved in bone homeostasis. It is expressed in the brain, kidneys and bladder [3].

BMPs play a role in the differentiation, proliferation, growth inhibition, and arrest of maturation of a wide variety of cells, depending on the cellular microenvironment and the interactions with other regulatory factors $[1,7]$. When BMPs bind to their cell surface receptors on mesenchymal cell, a BMP signaling cascade is activated. This results in the expression of genes that lead to the synthesis of macromolecules involved in cartilage and bone formation, and the mesenchymal cell becomes either a chondrocyte or an osteoblast. Implantation of this protein component of bone matrix resulted in a complex series of cellular events, including mesenchymal cell infiltration, cartilage formation, vascularization, bone formation, and ultimately remodeling of the new bone tissue along with population by hematopoietic bone marrow elements [8]. In addition to differentiation of cells into the chondrocyte lineage, BMPs have been shown to directly differentiate into cells of the osteoblast phenotype.

BMP7 induces the phosphorylation of SMAD1 and SMAD5, which in turn induce transcription of numerous osteogenic genes [6]. It has been demonstrated that BMP-7 treatment is sufficient to induce all of the genetic markers of osteoblast differentiation in many cell types [3].

Bone morphogenetic proteins (BMPs) form a family of growth factors originally isolated from extracellular 
bone matrix that are capable of inducing bone formation in unusual places. The expression, tissue localization, and function of BMP-7 (OP-1) during tooth development were studied in rodents. Patterns of BMP-7 gene expression and peptide distribution indicated that BMP-7 was present in dental epithelium during the dental lamina, bud, and cap stages [9].

Continuity defects of the mandible frequently result from tumor removal or significant trauma, and reconstruction of these defects can be difficult. For defects with extensive hard and soft tissue loss, microvascular free tissue transfer often provides an excellent reconstructive option. However, significant site morbidity as well as non ideal bone stock for dental implant rehabilitation may occur [10].

The development of bone morphogenic proteins (BMPs) has offered an alternative to traditional bone grafting, which has been the gold standard for oral and maxillofacial reconstruction [11]. Clinical application of BMPs has evolved to include defects of the facial skeleton including those involving the mandible and maxilla [12]. There have been many reports of the use of BMPs regarding orthopedic as well as alveolar augmentation. There have been few studies addressing the use of BMP in reconstructing critical-size defects of the mandible.

Alloplastic materials have been used alone and in conjunction with osteoprogenitor cells, as well as with BMPs to facilitate bone regeneration [13]. BMPs can be used to drive in vitro, in vivo, and ex vivo differentiation of adult-derived osteoprogenitor cells into bone-forming osteoblasts [14]. While BMPs hold great promise for craniofacial reconstruction, significant concern has been generated over the safety of the current available forms of rhBMP-7 due to reports of clinically operative site edema in applications of craniomaxillofacial and spinal sites [15]. The effects of direct application of exogenous BMPs to bone defects may also prove to be too unpredictable for clinical use. Some studies have shown that the application of rhBMP to the repair of the human spinal column is associated with resorption of vertebral bodies in certain cases [16]. Therefore future treatments involving the implantation of osteoblastic cells differentiated ex vivo from mesenchymal stem cells by exposure to BMPs may prove to be the safest and most efficacious mode of therapy [17]. Periodontal regeneration depends on four ideas. The signalling, cells, blood supply and scaffold need to target the tissue defect. Each of these elements plays an important role in the healing process. Cells provide the apparatus for new tissue growth and differentiation. Growth factors and proteins regulate the cellular activity causing stimulation of cells to differentiate and produce matrix toward the developing tissue. New vascular tissues provide the nutritional base for tissue growth and homeostasis. Scaffolds guide and create a template structure three-dimensionally to make possible the above processes critical for tissue regeneration. A major complication and limiting factor in the achievement of periodontal regeneration is the presence of microbial pathogens that reside on tooth surfaces as plaqueassociated biofilms [18]. Thus infection control is a key to periodontal therapy success.

The biological principle of using cell-occlusive barriers was described by Melcher on the repair potential of periodontal tissues [19]. It was found that guided tissue regeneration (GTR) could be motivated by removal of the epithelial and gingival connective tissue from periodontal defects. Providing space to maximize PDL cells, cementoblasts, and osteoblasts to migrate selectively, proliferate and differentiate within the periodontal defects help in promoting the reconstruction of the supporting tissue and attachment [20].

Cellulose membranes were the first biomaterial applied as surgical barriers for periodontal GTR, followed by expanded polytetrafluoroethylene (ePTFE) and a variety of absorbable polymers [21]. Currently used materials include polylactic acid, polyglycolic acid, polyglactin, and both soluble and non-soluble collagen barriers [22]. The use of non-absorbable barriers requires a second surgical procedure for barrier removal, usually performed after 4-12 weeks following surgery. Absorbable barriers made from synthetic polymers are biocompatible, and biodegradable through physicochemical hydrolysis. Collagen barriers, made of type I collagen from bovine or porcine tissues, are degraded through enzymatic processes that may take from 6-8 weeks to as long as 4-8 months. In comparison with non-absorbable barriers, the absorbable types display the advantage of easy adaptation to the defect area without need for barrier removal [23].

Scaffolds and implant materials have also been used for periodontal therapy and bone regeneration in bony defects. In order to improve the efficiency absorption of bioactive molecules into scaffolding materials may aid long term growth factor release. This can be done before or after fabrication of the scaffold [24]. Bioactive molecules integrated directly into a bioresorbable scaffold are released by a diffusion-controlled mechanism that is regulated by the pore sizes such that different pore sizes affect the tortuosity of the scaffold and in so doing control the release of protein [25]. The rate of growth factor release depends on the type and rate of degradation of the delivery device, and the rate of growth factor diffusion through pores of the scaffolds. This approach works efficiently as cell invasion into the scaffolds regulates the release of BMPs to heal craniofacial defects. Development of suitable controlled-release of the bioactive molecules devices and/or alternative mode of delivery is needed.

Several bioactive molecules have demonstrated strong effects in promoting periodontal wound repair in preclinical and clinical studies. These bioactive molecules include PDGF [26], IGF-I, basic fibroblast growth factor (FGF-2) [27, 28] TGF-1 BMP-2 -4 -7 and -12), and enamel matrix derivative (EMD) that have shown positive results in stimulating periodontal regeneration. In addition, PDGF, BMP-2, and BMP-7 have been shown to promote 
peri-implant bone regeneration [29].

\section{Material and Methods}

Sampling method for this research involved articles published from 2000 to 2016. Search engines included Google Scholar and PubMed, ScienceDirect were used to search for the related articles using key words: BMP-7, bony defects, rhBMP-7, recombinant gene therapy OP-1. 30 articles based on their titles and abstracts, were used for background information (Fig 2).

Inclusion criteria:

1. Studies that included patients with a history of treatment BMP-7 or OP-1.

2. Including patients from pediatrics to elderly of both sexes.

3. Patients who undergone surgical and non-surgical treatments for osteonecrosis of the jaw.

4. Dental journals only.

5. In vitro studies.

6. In vivo studies.

Exclusion criteria:

1. Animal studies and basic science.

2. Articles published before yr 2000 .

Materials were collected from Pubmed Cochrane collection and Science Direct.

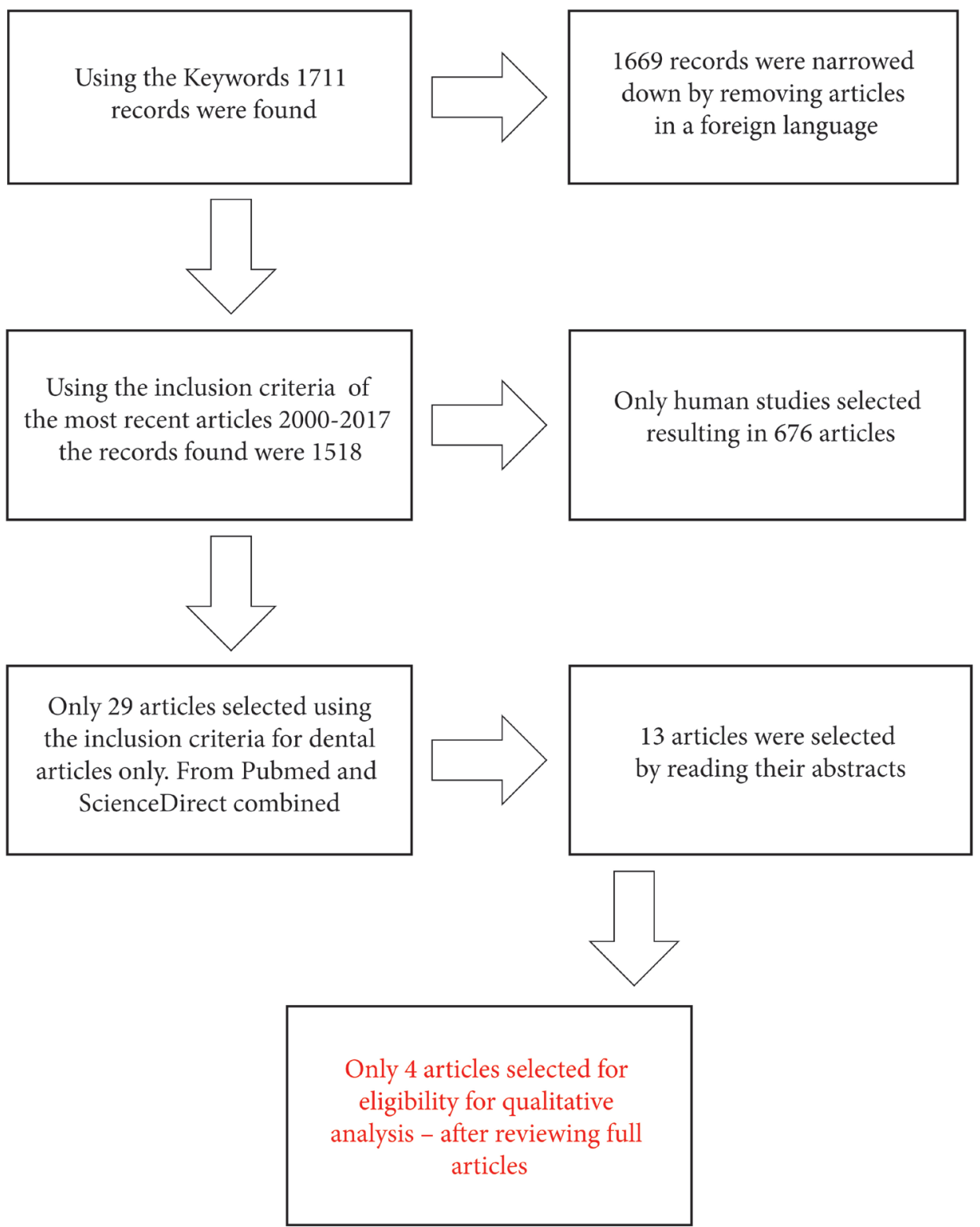

FIGURE 2. Flowchart showing how articles were selected using the inclusion and exclusion criteria 


\section{Results}

TABLE 1. Results - Articles Included in the Study and Relevance

\begin{tabular}{|c|c|c|c|c|c|c|}
\hline$\#$ & Authors & Year & Title & $\begin{array}{c}\text { Journal Full } \\
\text { Name }\end{array}$ & Abstract & Type of Study \\
\hline 1 & $\begin{array}{l}\text { Van den Bergh JP, } \\
\text { Ten Bruggenkate } \\
\text { CM, Groeneveld } \\
\text { HH, Burger EH, } \\
\text { Tuinzing DB. }\end{array}$ & 2000 & $\begin{array}{l}\text { Recombinant human } \\
\text { bone morphogenic } \\
\text { protein-7 in maxillary } \\
\text { sinus floor elevation } \\
\text { surgery in } 3 \text { patients } \\
\text { compared to } \\
\text { autogenous bone grafts. } \\
\text { A clinical pilot study. }\end{array}$ & $\begin{array}{c}\text { Journal of } \\
\text { Clinical } \\
\text { Periodontology }\end{array}$ & $\begin{array}{l}\text { Three patients with autologous } \\
\text { sinus grafts were compared with } \\
\text { three patients who had sinus lifts } \\
\text { with rhBMP-7. } 6 \text { months later } \\
\text { they were compared for resultant } \\
\text { bone growth. } 1 \text { patient treated with } \\
\text { rhBMP-7 showed vascularized, } \\
\text { quality bone }\end{array}$ & In vivo \\
\hline 2 & $\begin{array}{l}\text { Clokie CM, } \\
\text { Sándor GK }\end{array}$ & 2008 & $\begin{array}{l}\text { Reconstruction of } 10 \\
\text { major mandibular } \\
\text { defects using } \\
\text { bioimplants }\end{array}$ & $\begin{array}{l}\text { Journal of the } \\
\text { Canadian Dental } \\
\text { Association }\end{array}$ & $\begin{array}{l}\text { Ten patients with major } \\
\text { mandibular defects due to } \\
\text { ameloblastoma or osteomyelitis } \\
\text { were included in this study. } \\
\text { The resection defects were } \\
\text { reconstructed and held by plates } \\
\text { in the correct position. They were } \\
\text { filled with bioimplant containing } \\
\text { (BMP-7). After } 1 \text { year functional } \\
\text { and aesthetic reconstruction was } \\
\text { completed }\end{array}$ & In vivo \\
\hline 3 & $\begin{array}{l}\text { Zhi L, Chen C, } \\
\text { Pang X et al. }\end{array}$ & 2011 & $\begin{array}{c}\text { Synergistic effect } \\
\text { of recombinant } \\
\text { human bone } \\
\text { morphogenic protein-7 } \\
\text { and osteogenic } \\
\text { differentiation } \\
\text { medium on human } \\
\text { bone-marrow-derived } \\
\text { mesenchymal stem cells } \\
\text { in vitro. }\end{array}$ & $\begin{array}{l}\text { International } \\
\text { Orthopaedics }\end{array}$ & $\begin{array}{l}\text { The effect of rhBMP-7 with or } \\
\text { without osteogenic differentiation } \\
\text { medium (ODM) on hBMSCs in } \\
\text { vitro. The control test was done } \\
\text { with rhBMP-7 and ODM alone } \\
\text { with hBMSCs. The ALP, OCN, } \\
\text { OP and mRNA was examined. } \\
\text { Upregulated expression of these, } \\
\text { indicated a synergistic effect. }\end{array}$ & In vivo \\
\hline 4 & $\begin{array}{l}\text { Qin W, Zhu H, } \\
\text { Chen L, Yang X, } \\
\text { Huang Q, Lin Z. }\end{array}$ & 2014 & $\begin{array}{l}\text { Dental pulp cells } \\
\text { that express adeno- } \\
\text { associated virus } \\
\text { serotype } 2 \text {-mediated } \\
\text { BMP-7 gene enhanced } \\
\text { odontoblastic } \\
\text { differentiation. }\end{array}$ & $\begin{array}{c}\text { Dental Materials } \\
\text { Journal }\end{array}$ & $\begin{array}{l}\text { AAV2 mediated BMP-7 (AAV2 } \\
\text { BMP-7) was trialed to induce } \\
\text { odontoblastic differentiation } \\
\text { of human dental pulp cells } \\
\text { (DPSs). An increase in ALP } \\
\text { activity and mineralized nodules } \\
\text { showed promoted odontoblastic } \\
\text { differentiation. }\end{array}$ & In vivo \\
\hline
\end{tabular}

Table showing the articles chosen in order of dates published and the relevant information, the authors name and type of study

The study done by Clokie et al. (2008) showed the most successful results (Table 1) and the research carried out by Van den Bergh et al. (2000) showed similar success despite some limitations during their study. The studies carried out by Lianteng Zhi et al. and Wei Qin et al. (2011) also showed success in rhBMP-7 in vitro studies. The results found from the four research papers indicate a standardized use of BMP-7 molecules. Although delivery was different, all experiments used the BMP-7 molecules for the effect of bone regeneration. Some researchers used the BMP-7 along with osteogenic differential medium Lianteng Zhi et al. [30]. Whereas other research used BMP-
7 infected adeno-associated virus serotype 2 Wei Qin et al. [31]. Some research was found on BMP-7 delivery within implant scaffolds too which are discussed below [32]. Osteogenesis is an orchestrated process with engagement of committed mesenchymal stem cells, osteoprogenitors, osteoblasts and osteoclasts and is characterised by sequential expression of a cascade of relevant genes. The level of alkaline phosphatase (ALP) has been recognised as a functional biomarker of osteoblast differentiation [27] and calcium deposition in the extracellular matrix as an indicator of subsequent endochondral bone formation [30]. 
The research done by Lianteng Zhi et al. investigated the effect of recombinant human bone morphogenetic protein-7 (rhBMP-7) with or without osteogenic differentiation medium (ODM) on osteogenic differentiation of primary human bone marrow-derived mesenchymal stem cells (hBMSCs) in vitro. The osteoinductive ingredients in ODM include $\beta$-glycerophosphate $(5 \mathrm{mM}), \mathrm{L}$-ascorbic acid (50 $\mathrm{mg} / \mathrm{l})$ and dexamethasone $(10 \mathrm{nM})[30]$.

The authors say within the first few days the cells exposed to the BMP-7 with ODM showed morphological changes. Lianteng Zhi et al. showed that the minimal dose for inducing in vitro osteoblastic differentiation of hBMSCs was $0.1 \mu \mathrm{g} / \mathrm{ml}$ rhBMP-7. They also observed that rhBMP-7 did not cause calcium deposition in vitro culture of primary hBMSCs within the first 17 days, except for a moderate increase in calcium content in the ODM group with $1.0 \mu \mathrm{g} / \mathrm{ml} \mathrm{rhBMP}-7$. However, calcium deposit was significantly present with rhBMP-7 at concentrations of 0.1 and $1.0 \mu \mathrm{g} / \mathrm{ml}$ after 35 days of osteogenic differentiation in the presence of ODM (Fig 3). This period of time for calcium deposition corresponds well with the clinical timing of bone healing in humans. The experiment they did showed that alkaline phosphatase activity and calcium deposits in hBMSC culture were notably increased at different concentrations. The calcium content in hBMSC culture was $30 \%$ higher in the $1.0 \mu \mathrm{g} / \mathrm{ml} \mathrm{rhBMP}-7$ group than that in the $0.1 \mu \mathrm{g} / \mathrm{ml}$ rhBMP-7 group demonstrating a dose-dependent osteoblastic differentiation by rhBMP-7 ODM (Fig 3). However, the research mentioned the same

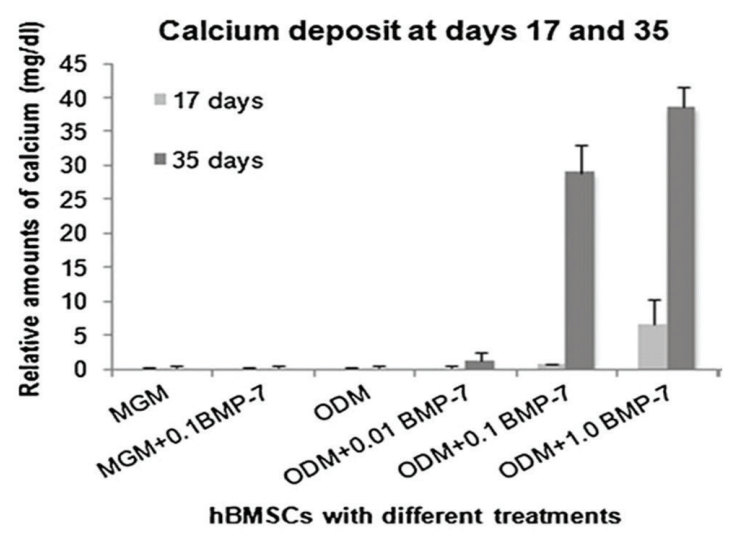

FIGURE 3. Results from the study by Zhi L et al [30]. The effect of rhBMP-7 on hBMSCs with and without ODM. Graph showing the amount of calcium deposited in the 6 different study groups.

dose of rhBMP-7 without ODM induced a lower level of ALP and calcium deposits. The same results were said to have been seen when the OD medium was used on its own. Lianteng Zhi et al. discuss that the result indicated a combined effect of rhBMP-7 and ODM on osteogenic differentiation. The authors used quantitative real-time reverse-transcriptase polymerase chain reaction (RTPCR) analysis and they say this showed up-regulated Osteopontin and Osteocalcin mRNA levels, which confirms the synergistic effect of rhBMP-7 and ODM. The study showed that rhBMP-7 with ODM had a combined synergistic effect on up-regulation of osteogenic genes as well as osteogenic differentiation of primary hBMSCs in vitro. In the presence of ODM, the researchers found that the lowest concentration of rhBMP-7 needed to induce significant osteogenic differentiation of hBMSCs was 0.1 $\mu \mathrm{g} / \mathrm{ml}[30]$.

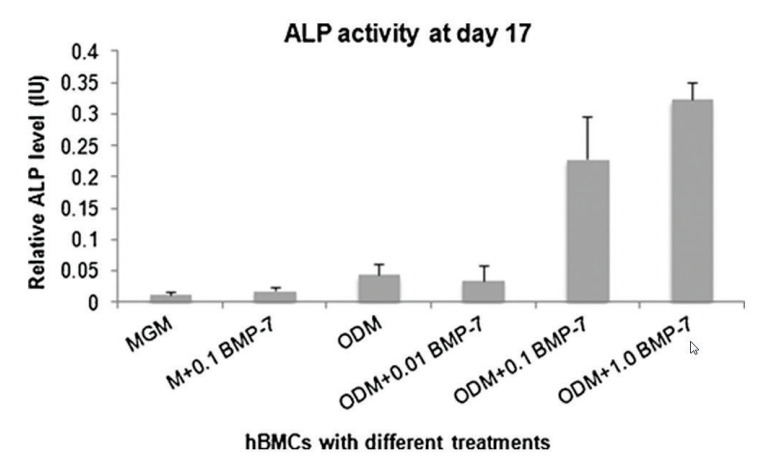

FIGURE 4. The ALP Activity in study groups [30] at day 17. Graph showing the ALP activity in the various different groups.

The study done by Wei Qin et al. investigated the potential of adeno-associated virus serotype 2 (AAV2) mediated BMP-7 (AAV2-BMP-7) to induce odontoblastic differentiation of human dental pulp cells (DPCs) in vitro. The authors used AAV2 to deliver BMP-7 and the biologic effects of the protein on dental pulp cells were tested by observing the activity of alkaline phosphatase, the expression of dentin sialophosphoprotein (DSPP) and osteocalcin (OCN). The proliferative ability of the cells was also analysed. Alkalinephosphatase was used as a marker as there was a higher level of ALP in differentiating odontoblastic cells when compared with undifferentiated mesenchymal cells [31]. To determine the function of BMP-7 on odontoblastic differentiation, the authors used ALP enzymatic assays to test ALP activity. ALP in the cells that were infected with AAV2-EGFP were said to have increased slightly with time. In contrast, the activity of ALP was significantly higher in AAV2-BMP-7-infected dental pulp cells. Wei Qin et al. found that after 14 days the formation of mineralized nodules showed an increased mineralization in dental pulp cells. These results suggested that BMP-7 promoted odontoblastic differentiation and mineralization in the dental pulp cells in vitro (Fig 5).

To assess if AAV2-BMP-7 could encourage odontoblastic differentiation, the expression levels of dentinsialophosphoprotein (DSPP) and Osteocalcin mRNA the authors used real-time PCR. They stated in their results that mRNA levels of DSPP and OCN in the AAV2-BMP-7 group were 7.03 times and 3.12 times higher than that in the control group at 7 days, respectively. Although the DSPP and OCN mRNA showed a decrease in expression with time, Wei Qin et al. say expression levels were higher than that of the control group. Together, the significantly increased levels of ALP activity and DSPP 

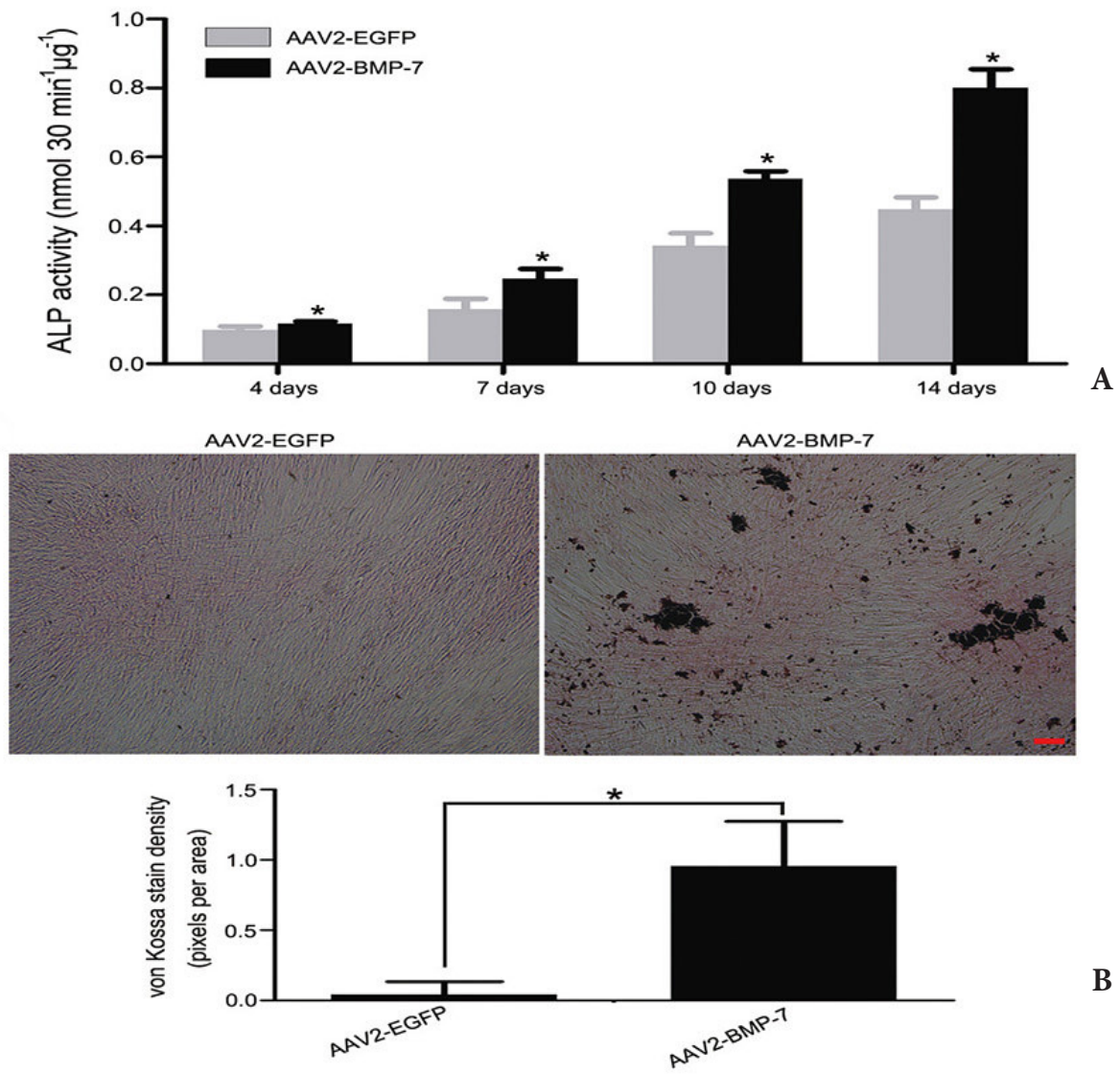

B

FIGURE 5. Results from the study by Wei Qin et al. [31]. (A) Graph showing ALP activity in the different study groups and control group. (B) ALP staining in the AAV2-EGFP control group and the AAV2-BMP-7 group.

and OCN mRNA in the AAV2- BMP-7 the authors say that BMP-7 promoted the differentiation of DPCs to odontoblast-like cells in vitro [31] (Fig 5).

The study done by J.P.A van den Bergh studied the bone formation by BMP-7 molecules with a collagen carrier. The BMP-7 molecules were implanted in the maxillary sinus of 3 patients. The research used three other patients with simple sinus floor elevation using autogenous bone grafts. The authors followed the patients for six months after the implants were placed. The researchers found the first patient who had a BMP-7 graft placed, had well integrated and vascularized bone tissue which they confirmed by using the histological examination. In the second female patient with BMP-7 graft there was said to be no bone formation observed. A cyst-like granular tissue mass was found was removed. The authors say the third patient who was also female and who received bilateral sinus grafts, slight bone formation was seen however it showed flexible tissue thus an implant placement was postponed. In all 3 patients with the autogenous grafted sinuses a bone appearance similar to normal maxillary bone was clinically seen and tested histologically. Dental implants could be placed six months after sinus floor elevation surgery. Van den Bergh et al. found that the BMP-7 molecule has the potential for initiating bone formation in the human maxillary sinus within 6 months after a sinus floor elevation operation [3].

Cameron M.L. Clokie et al. used ten patients, with ameloblastoma and osteomyelitis in the body or ramus of the mandible, as a sample. They used 4 males and 6 females. Their ages ranged from 18 to 73 years of age with a mean age of 43.1 years. They manually created a bioimplant, by mixing the BMP-7 with demineralized bone matrix, then molded it into the shape of the mandible using reverse phase medium and implanted into the bony defect. They covered and fixed the bioimplant in the defect then followed up the patients for a minimum of 9 months. Cameron et al talk about the clinical and radiographic evidence of restoration of mandibular continuity with no complications.

The authors say of the 10 patients, 4 had dental implants placed in their reconstructed mandibles. In one case, the implants were placed 8 years following the reconstructive surgery. An important point mentioned in the results of this research was that, in all 10 patients, bone formation was consistently first sensed on clinical examination during manual manipulation of the reconstructed segment. Radiographic evidence of bone formation was not fully evident until 1 year after the reconstructive procedure. However, at 1 year following reconstruction, the researchers found it difficult to differentiate between 

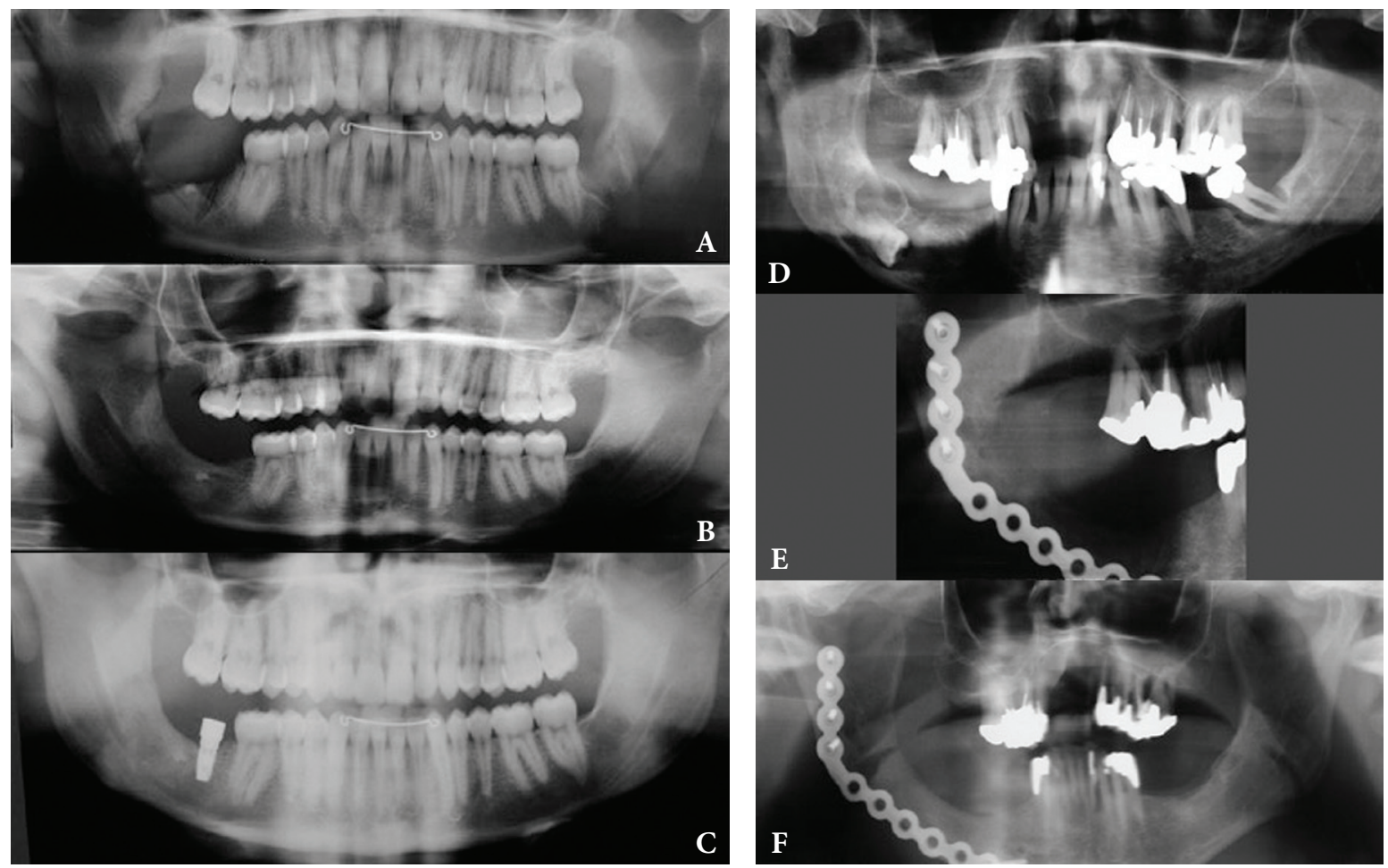

FIGURE 6. Radiographic images of patient in pre and post-implant treatment from the study by Clokie at al [32]. (A) radiograph of a 19-year-old boy post resectional surgery prior to implant placement. (B) 1 year after bioimplant with BMP-7 is placed. (C) 9 months post implant placement in 19 year old. (D) 62-year-old man pre-treatment (E) post treatment 6 months after bioimplant is placed. (F) 1 year post bioimplant placement bone formation.

bone that was formed from the BMP bio-implant and native pre-existing bone [32] see Figure 6.

\section{Discussion}

RhBMP-7 was used in different modalities in the four studies to test for the efficiency of rhBMP-7 in bone defects thus although difficult to compare the results from each study on a standardized scale it is easy to see the success in rhBMP-7 therapy studied by each author.

The study by Lianteng Zhi et al. ALP activity in hBMSC culture was significantly increased at $0.1 \mu \mathrm{g} / \mathrm{ml} \mathrm{rhBMP}-7$ and was further enhanced at the concentration of $1.0 \mu \mathrm{g} /$ $\mathrm{ml}$ in the presence of ODM. Their results showed that that there is a minimal dose threshold of BMP-7 required for inducing osteogenic differentiation of hBMSCs in vitro. Lianteng Zhi et al showed that the minimal dose for inducing in vitro osteoblastic differentiation of hBMSCs was higher than $0.1 \mu \mathrm{g} / \mathrm{ml} \mathrm{rhBMP-7}$ under synergistic effect of ODM. Although ODM without rhBMP-7 increased ALP activity above the baseline level, the ODM with $0.1 \mu \mathrm{g} / \mathrm{ml}$ rhBMP-7 induced a five-fold higher ALP level comparatively. There was also a significant difference of rhBMP-7-induced ALP levels between $0.01 \mu \mathrm{g} / \mathrm{ml}$ and $0.1 \mu \mathrm{g} / \mathrm{ml} \mathrm{rhBMP-7}$ concentrations in the presence of ODM. The authors observed that rhBMP-7 did not promote calcium deposit in vitro culture of primary hBMSCs at an earlystage. The scientists strongly believe that not just rhBMP-7 is responsible for the increases osteogenic activity but dexamethasone is also another factor that may interplay with rhBMP-7 to create the synergistic effect of ODM and rhBMP-7 observed in this study [32]. The objectives of this study to test the osteogenicity of rhBMP-7 has been proven by this author.

There have been several studies to test the effect of dexamethasone on BMP activity and using this data the authors state that not only was the BMP-7 successful with the ODM but the synergic effect could be attributable to the dexamethasone within the ODM however further studies are required [28]. When compared to the research done by Wei Qin et al. in which dental pulp cells that were infected with AAV2-BMP-7 showed notably increased ALP activity and formed mineralized nodules. AAV2BMP-7 also increased the expression of mineralizationrelated genes, which included DSPP and OCN. There was no considerable difference between the proliferative ability of AAV2-BMP-7 and the control group showing the virus was not cytotoxic. Compared to the rhBMP-7 used as a bone graft implant the results from this study showed less rhBMP-7 promoted the odontoblastic differentiation in the dental pulp cells than in the implanted grafts [28]. However the results having shown the expression of mineralization related genes indicate the therapeutic potential of AAV2-BMP-7 in dental tissue regeneration [30]. The later stage of odontogenic differentiation observed by Hakki et al. tells us that the rhBMP-7 stimulates ALP and biomineralization in a dose dependant manner to initiate differentiation of human 
periodontal ligament stem cells [33].

From the study by Cameron M.L Clockie et al it is seen that there was successful reconstruction of large mandibular defects. The author also found that there was sufficient restoration of mandibular height and width, which is very important and vital for functional prosthetic rehabilitation. Proper reconstruction also ensured that appropriate facial form was recreated. The authors stated that, patient morbidity and overall cost to the health care system, including length of hospital stay, were significantly reduced using this technique [27].

The synthetic bone used for these patients overcomes the problems associated with autogenous bone grafting as well as the limitations of finding donor sites. The BMP7 bio-implants showed the ability to copy the healing of natural bone and resorb and be replaced by autologous bone. Successful reconstruction of 10 major mandibular defects was achieved. Both functional and esthetic results were comparable if not better than those achieved with autogenous bone grafting [32].

In comparison the studies by Clokie et al. show a significant result with the BMP-7 molecules in defect sites. The study by Wei Qin et al. showed a promising use of BMP-7 in dental pulp cells causing osteogenic proliferation indicating the need for further studies so that it can be used in other oral and maxillofacial applications. Lianteng Zhi et al. shows a synergistic effect of the BMP-7 molecule associated with dexamethazone or ODM.

The most promising results faired from Clokie et al. study as it was done in vitro in large bone defects where implants were efficiently placed it would seem their research showed greatest success when compared with invitro studies. The studies done by Wei Qin et al. and Lianteng Zhi et al. are comparable as although different markers were used, rhBMP-7 was said to have contributed to 3 fold increase in OCN expression and a 30\% increase in calcium deposits in each study respectively [30, 32]. The second objective of this study was to test the ability of rhBMP-7 to regenerate bone in the oral and maxillofacial region. The bone deposit seen in the radiographs in Figure 6 show just this.

Van den Burgh et al. studied the biopsies of the first and third patients that were grafted with BMP and stated that sufficient bone formation was possible with the implantation of rhOP-1 in the human maxillary sinus, with a collagen delivery device, within a 6 months period. In addition, the bone volume percentage, osteoid surface percentage, and the presence of osteoblast in the area all demonstrate the fact that rhBMP-7 has got the ability to engage enough mesenchymal cells in the human maxillary sinus which leads to enough bone formation for the placement of dental implants. A similar result was seen in the study carried out by Clokie et al. Van den Burgh et al. discovered the first male patient case the bone tissue that was found was all lamellar bone. In the other 2 cases both of which were females, case 2 showed no bone formation whatsoever but there was a postoperative swelling on the patient's face 6 days post sinus grafting with the rhBMP-7. Case 3 of their study, on the other hand displayed a change with most of the immature bone present being lamellar while the rest portrayed a more woven appearance of bone. This was accompanied by a facial swelling 6 days after sinus grafting with rhBMP-7. Whether or not the detected swelling was caused by an unwanted tissue reaction to the rhBMP-7 or its carrier, and whether it has had a negative effect on the induction of bone, needs to be studied more in depth. According to the results found from this study, a more in depth analysis is required regarding the rhBMP-7. However results after 6 months are comparable to the study done by Clokie et al. only slightly differing in technique with the latter study having used a bioimplant and van den Burgh using an autologous graft. All the studies found suggest the success of rhBMP-7 in bone defect sites $[3,32]$.

\section{Conclusion}

Of all the research [33-38] that was included in this study and the papers we found that the BMP-7 molecule showed significance in bone development and differentiation.

The objectives of this study was to test the reliability and efficiency of rhBMP-7 in treating bone defects which was scientifically tested and brings us to the conclusion that it can be used effectively to treat bone defects. The study by Clokie et al. allows us to draw the conclusion that rhBMP-7 can be used effectively for bone loss treatments and in bone defects caused by disease such as osteomyelitis. We can also say that rhBMP-7 improves efficacy in the treatment of bony defects by reducing the hospital time as well the use of bioimplants also helps to reduce morbidity of autologous graft donor sites.

Previous studies on animals have also shown success rates in the use of rhBMP-7 in bone defect sites [28].

Over all despite the difference in methodology of each study reviewed in this research project we can conclude that rhBMP-7 is an efficient molecule for the therapy of bone defects, However further human studies are required to reinforce the use of rhBMP-7 in humans as results found in vitro studies are often not replicated when used in vivo.

\section{Funding}

None.

\section{Conflict of Interests}

The authors declare that they have no conflict of interest.

\section{Role of Author and Co-authors}

Nur Hatab (concept of the paper and editing). Tulsie Patel (material collection and writing). Aya Bakkour (material collection and writing). 


\section{Ethical approval}

Approval was obtained from the Medical Ethics Committee of the RAK Medical and Health Sciences University.

\section{Patient consent}

Not required.

\section{References}

1. Rao SM, Ugale GM, Warad SB. Bone morphogenetic proteins: periodontal regeneration. $N \mathrm{Am} \mathrm{J} \mathrm{Med} \mathrm{Sci}$ 2013;5(3):161-8. http://dx.doi.org/10.4103/19472714.109175.

2. Carranza FA: Bone loss and patterns of bone destruction. In: Newman MG, Takei HH, Carranza FA, editors. Carranza's Clinical Periodontology. 9th ed. Philadelphia: W.B. Saunders Company; 2002. p. 363.

3. Kaigler D, Cirelli JA, Giannobile WV. Growth factor delivery for oral and periodontal tissue engineering. Expert Opin Drug Deliv 2006;3(5):647-62. http:// dx.doi.org/10.1517/17425247.3.5.647.

4. Van den Bergh JP, ten Bruggenkate CM, Groeneveld $\mathrm{HH}$, Burger EH, Tuinzing DB. Recombinant human bone morphogenetic protein-7 in maxillary sinus floor elevation surgery in 3 patients compared to autogenous bone grafts. A clinical pilot study. J Clin Periodontol 2000;27(9):627-36.

5. Schilephake H. Bone growth factors in maxillofacial skeletal reconstruction. Int J Oral Maxillofac Surg 2002;31(5):469-84.

6. Chen D, Zhao M, Mundy GR. Bone morphogenetic proteins. Growth Factors 2004;22(4):233-41.

7. Shnayder Y, Lin D, Desai SC, et al. Reconstruction of the lateral mandibular defect a review and treatment algorithm. JAMA Facial Plast Surg 2015;17(5):367-73. http://dx.doi.org/10.1001/jamafacial.2015.0825.

8. Urist MR. Bone: formation by autoinduction, Science 1965;150(3698):893-9.

9. Wang EA. Bone morphogenetic proteins (BMPs): therapeutic potential in healing bony defects. Trends Biotechnol 1993;11:379-83.

10. Reddi AH. Cell biology and biochemistry of endochondral bone development. Coll Relate Res 1981;1:209-26.

11. Itoh F, Asao $\mathrm{H}$, Sugamura $\mathrm{K}$, Heldin $\mathrm{CH}$, ten Dijke $\mathrm{P}$, Itoh S. Promoting bone morphogenetic protein signaling through negative regulation of inhibitory Smads. EMBO J 2001;20(15):4132-42. http://dx.doi. org/10.1093/emboj/20.15.4132.

12. Helder MN, Karg H, Bervoets TJ, Vukicevic S, Burger EH, D'Souza RN, Wöltgens JH, Karsenty G, Bronckers AL. Bone morphogenetic protein-7 (osteogenic protein-1, OP-1) and tooth development. J Dent Res 1998;77(4):545-54. http://dx.doi.org/10.1177/0022034 5980770040701.

13. Bostrom MP, Seigerman DA. The clinical use of allografts, demineralized bone matrices, synthetic bone graft substitutes and osteoinductive growth factors: a survey study. HSS J 2005,1(1):9-18. http://dx.doi. org/10.1007/s11420-005-0111-5.

14. He TC. Distinct osteogenic activity of BMPs and their orthopaedic applications. J Musculoskelet Neuronal Interact 2005;5(4):363-6.

15. Lee KB, Murray SS, Taghavi $\mathrm{CE}$ et al. Bone morphogenetic protein-binding peptide reduces the inflammatory response to recombinant human bone morphogenetic protein-2 and recombinant human bone morphogenetic protein-7 in a rodent model of soft-tissue inflammation. Spine J 2011;11(6):568-76. http://dx.doi.org/10.1016/j.spinee.2011.02.001.

16. Laursen M, Høy K, Hansen ES, Gelineck J, Christensen $\mathrm{FB}$, Bünger CE. Recombinant bone morphogenetic protein-7 as an intracorporal bone growth stimulator in unstable thoracolumbar burst fractures in humans: preliminary results. Eur Spine J 1999;8(6):485-90.

17. Chenard KE, Teven CM, He TC, Reid RR. Bone morphogenetic proteins in craniofacial surgery: current techniques, clinical experiences, and the future of personalized stem cell therapy. Journal of Biomedicine and Biotechnology 2012; Volume 2012:1-14. http:// dx.doi.org/10.1155/2012/601549.

18. Slots J, MacDonald ES, Nowzari H. Infectious aspects of periodontal regeneration. Periodontology 2000 1999;19:164-72.

19. Melcher AH. On the repair potential of periodontal tissues. J Periodontol 1976;47:256-60.

20. Aukhil I, Pettersson E, Suggs C. Guided tissue regeneration. An experimental procedure in beagle dogs. J Periodontol 1986;57:727-34.

21. Gottlow J, Nyman S, Karring T, Lindhe J. New attachment formation as the result of controlled tissue regeneration. J Clin Periodontol 1984;11:494-503.

22. Christgau M, Bader N, Felden A, Gradl J, Wenzel A, Schmalz G. Guided tissue regeneration in intrabony defects using an experimental bioresorbable polydioxanon (PDS) membrane. A 24-month splitmouth study. J Clin Periodontol 2002;29:710-23. http://dx.doi.org/10.1034/j.1600-051X.2002.290808.x.

23. Oh TJ, Meraw SJ, Lee EJ, Giannobile WV, Wang HL. Comparative analysis of collagen membranes for the treatment of implant dehiscence defects. Clin Oral Implants Res 2003;14:80-90.

24. Fournier N, Doillon CJ. Biological moleculeimpregnated polyester: an in vivo angiogenesis study. Biomaterials 1996;17:1659-65.

25. Babensee JE, McIntire LV, Mikos AG. Growth factor delivery for tissue engineering. Pharm Res 2000;17:497504.

26. Giannobile WV, Lee CS, Tomala MP, Tejeda KM, Zhu Z. Platelet-derived growth factor (PDGF) gene delivery for application in periodontal tissue engineering. $J$ Periodontol 2001;72:815-23.

27. Orimo H, Shimada T. The role of tissue-nonspecific alkaline phosphatase in the phosphate-induced activation of alkaline phosphatase and mineralization in SaOS-2 human osteoblast-like cells. Mol Cell Biochem 2008;315:51-60. 
28. Leboy PS, Beresford JN, Devlin C, Owen ME. Dexamethasone induction of osteoblast mRNAs in rat marrow stromal cell cultures. J Cell Physiol 1991;146:370-80.

29. Taba M Jr, Jin Q, Sugai JV, Giannobile WV. Current concepts in periodontal bioengineering. Orthod Craniofac Res 2005;8(4):292-302. http://dx.doi. org/10.1111/j.1601-6343.2005.00352.x.

30. Zhi L, Chen C, Pang X et al. Synergistic effect of recombinant human bone morphogenic protein-7 and osteogenic differentiation medium on human bonemarrow-derived mesenchymal stem cells in vitro. International Orthopaedics 2011;35:1889-95. http:// dx.doi.org/10.1007/s00264-011-1247-1.

31. Qin W, Zhu H, Chen L, Yang X, Huang Q, Lin Z. Dental pulp cells that express adeno-associated virus serotype 2-mediated BMP-7 gene enhanced odontoblastic differentiation. Dent Mater J 2014;33(5):656-62.

32. Clokie CM, Sándor GK. Reconstruction of 10 major mandibular defects using bioimplants containing BMP7. J Can Dent Assoc 2008;74(1):67-72.

33. Hakki SS, Bozkurt B, Hakki EE, Kayis SA, Turac G, Yilmaz I, Karaoz E. Bone morphogenetic protein-2, -6, and -7 differently regulate osteogenic differentiation of human periodontal ligament stem cells. J Biomed Mater Res B Appl Biomater 2014;102(1):119-30. http://dx.doi. org/10.1002/jbm.b.32988.

34. Betz, Volker M. et al. An expedited approach for sustained delivery of bone morphogenetic protein-7 to bone defects using gene activated fragments of subcutaneous fat. J Gene Med 2016;18:199-207.

35. Herford AS, Boyne PJ, Williams RP. Clinical applications of rhBMP-2 in maxillofacial surgery. J Calif Dent Assoc 2007;35(5):335-41.

36. Jain A, Pundir S, Sharma A. Bone morphogenetic proteins: the anomalous molecules. I Indian Soc Periodontol 2013;17(5):583-6.

37. Giannobile WV, Hernandez RA, Finkelman RD, Ryan S, Kiritsy CP, D’Andrea M, et al. Comparative effects of platelet-derived growth factor-BB and insulin-like growth factor-I, individually and in combination, on periodontal regeneration in Macaca fascicularis. $J$ Periodontal Res 1996;31:301-12.

38. Murakami S, Takayama S, Ikezawa K, Shimabukuro Y, Kitamura M, Nozaki T, et al. Regeneration of periodontal tissues by basic fibroblast growth factor. $J$ Periodontal Res 1999;34:425-30. 
Hatab N, Patel T, Bakkour A.

The efficiency of rhBMP-7 in oral and maxillofacial bone defects: a systematic review.

J Diagn Treat Oral Maxillofac Pathol 2017;1:77-88.

http://dx.doi.org/10.23999/j.dtomp.2017.2.5.

Ефективність рлКМБ-7 при оральних і щелепнолицевих кісткових дефектах: загальний огляд

\section{Нур Хата61, Тулсі Патель², Ая Баккур³}

РАК Коледж стоматологічних наук, РАК Університет медичних і наук здоров'я, Рас-Аль-Хайма, Об'єднані Арабські Емірати (ОАЕ) 1 Старший лектор, доктор фрілософії зі щелепно-лицевої хіругї

${ }^{2}$ Студент, бакалавв з хірургічної стоматології
${ }^{3}$ Студент, бакалавр з хірургічної стоматології

\section{П Р О С ТАТ Т Ю}

\section{P E 3 Ю M E}

Історія рукопису:

Отриманий: 10 червня 2017 року Прийнятий: 11 червня 2017 року Онлайн з: 30 червня 2017 року

Ключові слова:

Рекомбінантний людський кістковий морфогенний білок-7 (рлКМБ-7)

Рекомбінантна терапія

Остеогенний білок-1 (ОБ-1)

Направлена тканина регенерація (HTP)
Мета. Кістковий морфогенетичний білок-7 (КМБ-7) - це молекула, яка була клінічно випробувана та випробувана для використання при регенерації кісткових дефектів та ії здатності індукувати утворення кісток завдяки індукції експресії генів [11]. Рекомбінантний людський КМБ-7 (рлКМБ-7) застосовується в хіургії і продається під маркою остеогенний білок (ОБ-1) (Олімпус Біотек Корпорейшин). При постійному розвитку спеціальності та необхідністю регенеративної терапії при дефектах кісток в оральній та щелепно-лицевій хірургіï, це дослідження було проведено для порівняння результатів різних методів застосування КМБ-7.

Методи. Автори отримали англійські публікації про відповідні дослідження з PubMed, ScienceDirect та Google Scholar з 2000 по 2016 pp. Дослідження in vitro та in vivo були включені. Основними результатами було посилення експресії остеогенних генів та заповнення кісток на рентгенограмах.

Результати. Загалом в літературі було виявлено 676 досліджень, але в кінцевому підсумку було обрано лише чотири дослідження для аналізу. Результати показали суттєвий ефект рлКМБ-7 як in vitro, так i in-vivo. У всіх дослідженнях, проведених систематичним оглядом, було використано порівняння результатів використання рлКМБ-7. Зразки in vivo демонстрували значне радіографічне наповнення та ефективне осадження кісток [4]. Дослідження in vitro свідчать про посилення експресіі біомаркерів OCN та ALP.

Висновки. РлКМБ-7 $є$ ефективним інструментом, який може бути використаний для покращення та прискорення регенеративної терапії кісткових дефектів. Проте подальші дослідження людини необхідні для посилення та розвитку використання цієї молекули in vitro.

\section{Эффективность рчКМБ-7 при оральных и челюстно- лицевых костных дефектах: общий обзор}

\section{Нур Хата61', Тулси Патель², Ая Баккур³}

РАК Колледж стоматологических наук, РАК Университет медицинских и наук здоровья, РасАль-Хайма, Объединенные

${ }^{2}$ Студент, бакалавр хирургической стоматологи

${ }^{3}$ Студент, бакалавр хируреической стоматологии

\section{O C TATbE}

История рукописи:

Получена: 10 июня 2017 года Принята: 11 июня 2017 года Онлайн с: 30 июня 2017 года

Ключевые слова:

Рекомбинантный человеческий костный морфогенетический белок-7 (рчКМБ-7)

Рекомбинантная терапия

Остеогенная белок-1 (ОБ-1) Направлена тканевая регенерация (HTP)

\section{P E 3 Ю M E}

Цель. Костный морфогенетический белок-7 (КМБ-7) - это молекула, которая была клинически испытана и проверена для использования при регенерации костных дефектов и его способности индуцировать образование костей благодаря индукции экспрессии генов [11]. Рекомбинантный человеческий КМБ-7 (рчКМБ-7) применяется в хиургии и продается под маркой остеогенная белок (ОБ-1) (Олимпус Биотек Корпорейшин). При постоянном развитии специальности и необходимостью регенеративной терапии при дефектах костей в оральной и челюстно-лицевой хирургии, это исследование было проведено для сравнения результатов различных методов применения КМБ-7.

Методы. Авторы получили английские публикации о соответствующих исследованиях с PubMed, ScienceDirect и Google Scholar с 2000 по 2016 Исследования in vitro и in vivo были включены. Основными результатами было усиление экспрессии остеогенных генов и заполнения костей на рентгенограммах. Результаты. Всего в литературе было обнаружено 676 исследований, но в конечном итоге был избран лишь четыре исследования для анализа. Результаты показали существенный эффект рчКМБ-7 как in vitro, так и in-vivo. Bo всех исследованиях, проведенных систематическим обзором, было использовано сравнение результатов использования рчКМБ-7. Образцы in vivo демонстрировали значительное радиографическое наполнения и эффективное осаждение костей [4]. Исследования in vitro свидетельствуют об усилении экспрессии биомаркеров OCN и ALP. Выводы. РчКМБ-7 является эффективным инструментом, который может быть использован для улучшения и ускорения регенеративной терапии костных дефектов. Однако дальнейшие исследования человека необходимы для усиления и развития использования этой молекулы in vitro. 